\title{
The Romanian Migrant Communities of Italy. A Case Study in Ostiglia, Lombardy
}

\author{
Mihai Pascaru \\ "1 Decembrie 1918" University of Alba Iulia, Romania \\ Andreea Elena Nicoara \\ "Apuseni Mountains" Research and Socio-Economical Development Centre \\ of Alba Iulia, Romania
}

doi: 10.19044/esj.2016.v12n22p1 URL:http://dx.doi.org/10.19044/esj.2016.v12n22p1

\begin{abstract}
The theoretical foundation of the current study consists in the distinction between community and society proposed by Ferdinand Tönnies in a famous 1887 book. Building upon this foundation and upon the results of a qualitative research survey of the Romanian migrants in the city of Ostiglia, Italy, the study will attempt sketching some answers to the following questions: 1) Do Romanian migrants constitute a particular community where they work?; 2) What is the role of the Church in the structure of the community life?; 3) What role do leisure time activities play in the consolidation of the community life?; 4) What role can the constitution of a real community have in its members' decisions to remain abroad on a permanent basis? The data was collected through a series of semi-structured interviews. We found that the Romanian migrants from Ostiglia tend to congregate into a temporary community, their communal ties being enhanced by the existence of a Romanian church in the Italian city. Shared leisure time also fortifies intra-community ties. Nevertheless the community is not a critical factor in migrants' decision to leave or permanently remain in Ostiglia.
\end{abstract}

Keywords: Community, society, inter-knowledge, communication, mutual support, migrants

\section{Introduction}

The community has always been and still is the most suitable framework for human evolution and manifestation, anthropologically speaking. Perhaps that is why the notion of community has particular meanings for each of us. According to Bauman "community" is another name for the lost paradise to which we feverishly seek the return paths 
(Bauman, 2002, p. 3). Through the community, be it family, neighbourhood or comradeship, man both lives and survives. From that perspective, the community becomes important in the context of the migratory phenomena of this century. When migrating, the individuals leave their communities of origin and long for a certain communitarian security at their destination.

Starting from these premises we will try to sketch certain aspects of a possible desired and sometimes achieved communitarian life of the Romanian immigrants in Ostiglia, Italy. Although the descriptive feature of the study is the likely outcome of the qualitative methodology used, some hypotheses with a more consistent theoretical relevance may emerge from the conclusions.

\section{The Community, Its Types and Its Dimensions}

The notion of community, as the authors of Penguin's Books' Dictionary of Sociology remarked, is one of the most elusive and vague concepts in sociology and having failed to acquire a specific meaning up to that point (Abercombie et al., 1988, p. 44). Smelser also noted at one point that the term "community" has so many meanings and uses, that it is nearly impossible to define with clarity (Smelser, 1981, p. 144). Whenever the community is defined in respect to society, references to Tönnies' 1887 groundbreaking work Gemeinschaft und Gesellschaft are inevitable, Tönnies' distinction between community and society constituting a valuable contribution to social science (Leif, 1979).

Tönnies looked at several types of community: 1) kinship, 2) neighborhood and 3) friendship. Kinship, Tönnies states, implies the possession and common use of the goods, and the common worship of ancestors. The neighbourhood is the general characteristic of the village life, where the dwellings' closeness and the plots' borders - viewed as simple territorial limits - determine numerous human contacts. The ability of living together rests on mutual knowledge and trust, and requires effort and order keeping to administer common goods. Friendship differentiates from kinship and neighbourhood through an identity in the conditions of work and, as a result of the former, an identity in thinking.

The Romanian sociologist Ion Aluaş appreciated that one may adopt the term "community" for the "sociology of the community" purposes and then attach the word "territorial" when trying to be more specific as to the community under debate (Aluaş, 1998, p.11). By the term "territorial community" Ion Aluaş says, one designates a certain spatial distribution of a group's residence and work places, and a relationship among these, respectively a structure composed of the relationship among them (Aluaş, 1998, p.12). 
For Mihăilescu (2003), the territorial community represents a group of people who live under a certain social division of work, in a particular geographical area, who have a common culture and a social activity organization system, and who are aware of their belonging to the respective community (Mihăilescu, 2003, p. 264). The Romanian sociologist considered the territorial community as being the core nucleus of what one calls social space and within which the place of work, the place of residence and the path between them interrelate in a certain unity. The main role belongs to the workplace, Mihăilescu stresses. The mobility of workplaces determines the mobility of the residency, the immobility of workplaces determining the immobility ("sedentarisation") of the residency (Mihăilescu, 2003, p. 264).

For our purposes we coined the term "community matrix" to be used in the research of territorial communities, a concept identified through three tightly linked dimensions: inter- knowledge, communication and mutual support (Pascaru, 2003a; Pascaru, 2003b, Pascaru, 2003c). We shall see how elements of this perspective suggested by us some years ago may come useful when analyzing the migrant communities overseas.

\section{The Romanian Migrant Communities in Italy; Some Observations}

Cingolani once remarked that the presence or Romanians in Italy recorded a remarkable evolution in regard to age structure and gender. Namely, while in the first half of the nineties the typical migrant was a single or married man followed at a later time by his wife, during the latter half of the decade the women started to arrive first and their husbands' second, and then the grandmothers start arriving to take over the care of their overseasborn nephews and nieces (Cingolani, 2009, p.184).

This migration pattern we appreciate is also valid with Romanians leaving for other European countries, Spain in particular. From communitarian perspective, what appears to be dominant is the community of blood according to authors like Cingolani. Only that the family becomes a trans-national family.

What role is there left for the other types of community, namely the neighbourhood and the friendship? We shall attempt to find an answer in our research data. For the time being we will recall Cingolani's claim that the relationships between Romanians are centred on kinship. Outside the relatives' circle, relationships are based on rational self-interest which defines the society and not the community according to Tönnies. Says Cingolani: "The communitarian dimension has suffered continuous erosion towards individualism. Many migrants denounce a lack of collective collaboration even among people coming from the same places of origin." (p.191). The sociologist Dumitru Sandu made similar observations in connection to the Romanian migrant communities from Madrid, Spain: "... 
social relationships between persons from the same community or from the same regions of origin are weaker. Accordingly, the integration in the receiving community is easier." (Sandu, 2010, p. 138).

Another notable remark made by Cingolani is about the role that the Church plays in the process of consolidating the identity of migrant Romanians and of solidarity building in the community: the religious activity participation represents an important and distinctive identity feature. In the inner space of the religious community Cingolani says, one becomes a Romanian again, while at work one gets dispersed and homogenized with the rest of the local population.

\section{A Qualitative Research in the Romanian Migrant Community from Ostiglia, Lombardy}

The considerations that follow are based on a series of eighteen spring 2015 interviews with Romanian migrants from the Italian city of Ostiglia. The respondents originate from several regions of Romania, namely Transylvania, Maramures and Moldova. The semi-structured interview guide was designed to elicit answers to questions like: 1) Do Romanian immigrants constitute an identifiable community where they work?; 2) What is the role of the Church in the structure of community life?; 3) What role do leisuretime activities play in the consolidation of community life?; 4) What role can the constitution of a true community have in the decision to take permanent residence overseas?

In regard to integration, the initial answers were positive: "Here we get along well with the other Romanians. They are accommodating. We came to know several Romanians here..." [B.O., F(emale), 28 (years old)]. By insisting with the question "How well do you know the Romanians in the area?" we elicited answers like: "I started to befriend Romanian girls and slowly I made friends. We exchanged telephone numbers and whenever we went out, we rang each other and we met... We walked together; we told each other stories..." (S.C., F., 24); "...I don't know too many Romanians. We are few Romanian neighbours... We get along well, we go out sometimes, although I don't have much time for that because of my work" (G.P., F., 38). The premises for bonding between Romanians rest on the Romanian origins, on the common work place and other elements they share: "We have a lot more in common with the Romanians. We have the love for the country back home, we have a common workplace and other things" (S.C. F. 24). The Church also has an important role: "[I know] approximately 50 Romanians. My source of information on the other Romanians is the Church. Only there do I constantly meet new people." (E.M., F., 22). We shall however return to the role of the Church at a later time. 
The inter-knowledge dimension has been tested also with the question "Are there persons of whom you know everything about?" One of the respondents underlined the impossibility of reaching such a high knowledge threshold, the reasons having to do with human nature: "Sincerity being a scarce commodity these days, we seldom know everything about someone. If we add to that the fact that very few people are brave enough to be who they truly want to be and not pretend to be someone else, then it becomes really hard to truly know the person next to you in a community. This would only be possible in a healthy, ethical principle-based society." (E.M., F., 22). Another reason for failing to achieve such a level of knowledge is simply a lack of interest for the matter: "I don't really know everything about certain persons [because] I don't care to know it... Most things that I know are about my family, even if it is far away." (G.P., F, 38).

The communication dimension was frequently centred on the daily life: "Romanians out here are very friendly; I like to talk to those to whom I already have a friendly relationship. I don't talk just when needed, I sometimes go out to meet them, so we can talk, see how they're doing, see if they'll alright. With one of my friends I discuss about the University ${ }^{1}$, about movies, we laugh together. With another lady I talk house things: how to cook certain dishes, housekeeping stuff" (E.M., F, 22); "We sometimes go out with the people we know or they come to our place. We talk about everything, about who has done what... I talk to the girls about what we should cook, what we should buy, about what's new... There are enough subjects and I can say we're like a family... They are the same age as us and they're ok." (V.C., F., 19);"We go out for holidays, a group of 12-14 people, and we keep in touch, within this circle that is... We recount how life was in Romania, on what we are doing every day." (B.O., F., 28).

In regard to the mutual support among the Romanian immigrants, the answers frequently expressed a positive perception: "If one needs any kind of help, we help each other. You know the saying: if a Romanian sets sail, he finds his own everywhere he goes..." (B.O., F.28). "We help each other when something happens and one of us is stuck... Say one doesn't have a car... Someone will take him places, take him shopping." (V.C., F.,19). "Of course we help each other, it depends on how busy we are, but if someone needs my help, I will offer it full heartedly... Me too, if I call for help, I will find it... Even when people are mean and they don't want to help... They are envious when someone earns more or succeeds faster, and he gets a house, gets a car... The others can't stand it anymore and that's when envy starts and the lack of help among us." (T.I., M., 27); "We help each other also when we go shopping..." (R.D., F., 27).

\footnotetext{
${ }^{1}$ The interviewee was a student.
} 
When asked to evaluate the extent to which the Romanians in Ostiglia have managed to live in a community, the interviewees offered some relevant answers like: "We are from Ardeal (i.e. Transylvania), most of us. Maybe that's what binds us. We have common habits and a common worry: we miss home, really miss it! We would leave in an instant, but we know there is no work back home. Is no home here, but it's fine... We sometimes go out with friends and check the surroundings; we sometimes go to the sea side or visit tourist objectives. We go to Church together and to other activities here." (B.O., F., 28). "We are all united; it doesn't matter where we're from. The fact that we are away from home binds us together. When they have lunches ${ }^{2}$ or festive days we meet, we eat cabbage rolls, and we listen to Romanian songs. We feel close, like at home. The only things missing are the other members of the family." (E.M., F., 22). "Some are living like in a community, others don't... United, not quite... Every one for himself, just like everywhere... Every one for himself... It's all about money... It's money that ruins friendships, when one makes more and the other less... There is a lot of envy on what one makes or what one buys."(G.P., F., 38).

As to the importance of the Church, many felt that it has an important role to play in the building of a community spirit: "The Church has a very important role; practically it is what keeps the Romanians together. It is the place where Romanians gather in large numbers. That is where they see each other, talk to each other, and visit each other. Without the Church they would lose contact. They go to church on every Sunday. I like to meet the others, from both this city and others. It is the place where people are at peace, where they enjoy seeing each other, they even laugh, where they help each other, establish relationships." (E.M., F., 22); "I believe it [the Church] unites us... For example during holidays we gather at the Church... I think this comes from our tradition from Romania. We talk, we share advice, it's nice." (C.O., F., 21). "The Church plays a very important role in the community for it keeps us together regardless of the area [of origin], and regardless of who we are. I go to Church when I have some time and when I go I use the opportunity to talk to acquaintances and to make new ones. I think if it weren't for the Church, we would not be so united." (M.A., F., 24).

Those that did not integrate well in the community were not going to the Church either: "I... came four month ago... I heard there is [a church], but I haven's gone. I don't know why, I don't have a reason... I just didn't go... Maybe I will in the future." (V.C., F, 19).

Our scientific interest focused at one point on the role played by leisure time activities in the consolidation of relationships between Romanian immigrants. Interviewees' comments are quite interesting on that

\footnotetext{
${ }^{2}$ Religious celebrations.
} 
issue: "Leisure time activities in the community are quite important as they have a role to play in keeping the unity. Such instrumental things are our Saturday evening meetings where everyone has a chance to share his or her experiences and opinions." (E.M., F., 22). "It sometimes happens when there is one of our celebrations, like December $1 s t^{3}$ for instance, that one organizes lunches downtown to a Romanian shop ${ }^{4}$, they sing the anthem, they make cabbage rolls and 'mici' (grilled sausages) like they do back home... It sometimes happens on Sundays that more Romanians gather to make a barbecue... That's how they meet... Usually parents get together and bring their children, they make a barbecue, they tell stories, share a glass of something..." (S.C., F., 24). Interviewees also stated that "gatherings are also welcome when the priest gets the people together to talk about the community and about things that are missing..." stressing at the same time that "would be good to have a centre where one can get together, one hopes that will be build someday..." (M.M., F., 46).

When looking to see what chances does the building of a true Romanian community in Ostiglia has in the respondents' representations, we discovered that the interviewees already were confirming the existence of it: "... I say a community has already formed since we help each other..." (T.I., M., 27). "A community was build here because we are many and... we are united." (M.A., F., 24).

We were also interested through our research in the extent to which the consolidation of a community of Romanian migrants in Ostiglia might influence its members' decision to either take permanent residence or return to the home country. Most answers revealed a firm decision to return home in the future: "I keep wishing to go home... I don't want to stay here... I want home, in Romania." (B.O., F., 28). "As far as I'm concerned, my country is my home and I only stay in Italy to provide for a better future back home, the bread is nowhere as good as the one back home." (G.N., M., 26). "I wish to go home... Here I see the future only in terms of money, but in life money is not all that counts." (F.I., M., 20).

\section{Conclusion}

Our research data on Romanian migrants to Ostiglia, Italy, lead us to the conclusion that some elements of communitarian life can be identified, but without meeting the ideal type of community described by Tönnies. Within the German sociologist's framework however, one may consider the case in Ostiglia as being a genuine Romanian neighbourhood, lacking the territorial element that would make it a true territorial community. The

\footnotetext{
${ }^{3}$ National Day in Romania.

${ }^{4}$ Local shop selling Romanian traditional items.
} 
Romanian residents are dispersed into many areas of the city without occupying a clearly delimited territory. The results point towards more of a Tönnies' friendship type of community. Within this space, the family communities are functioning like multiple nuclei. By delving deeper into the findings one may also discover here the presence of a amoral familism (Banfield, 1958; Mendras, 1989) as long as the family interests come before the communitarian ones. Strong social glue is provided by the Orthodox Church, the religious community overlaying the one resulting from the common origin of the migrants. Through Sunday mass and periodic celebrations the Church creates opportunities for getting together, occasions during which region-based clustering tendencies are also overcome. The church's specific climate fosters growth of new relationships among migrants and strengthens the existing ones. To that end one respondent remarked that "... If it weren't for the Church, we wouldn't be so united."

Leisure time consolidates the communitarian dimension of Ostiglia's Romanians with annual "national community belonging" resuscitation moments. We conclude that the community of origin model was at least partially reconstructed abroad. The Church and the village pub as significant centres of communitarian activity back home, appear to reproduce in Ostiglia where a family of Romanians opened a commercial outlet offering traditional Romanian items.

From the point of view of community's dimensions, Romanians in Ostiglia seem to favour the communication dimension, without being necessarily followed by inter-knowledge or high-level mutual support like one finds in a traditional village environment.

A community like that of Ostiglia's Romanian migrants' remains however a temporary community, the majority of the responding members stating they intend to return home eventually. Even so, we consider that some community development projects (Sandu, 2005; Buţiu, 2007) can and should be implemented in Romanian communities abroad. We support the idea also because, as one of the interviewees clearly articulated the case for them, there is a need for cultural centres around which Romanian Diaspora can congregate and establish or strengthen community ties.

\section{References:}

Abercombie, N., Hill, S., Turner, A. \& Bryan, S. (1988), Dictionary of Sociology, London, Penguin Books.

Aluaş, I. (1998), Sociologia comunităţilor, Studia Universitatis BabeşBolyai. Sociologia, XXV, nr. 2, pp. 11-41.

Banfield, E.C. (1958), The Moral Basis of a Backward Society, Glencoe, The Free Press. Bauman, Z. (2002[2001]), Comunitatea. Căutarea siguranţei într-o lume nesigură, Bucureşti, Antet. 
Buţiu, C.-A. (2007), "Dezvoltarea comunitară - Concept, strategii şi metode de intervenţie", in Pascaru, M. şi Buţiu, C.-A. (2007), Restituirea rezultatelor şi dezvoltarea comunitară, Editura Argonaut, Cluj-Napoca, pp. 37-92.

Cingolani, P. (2009), "Prin forţe proprii. Vieţi transnaţionale ale migranţilor români din Italia", in Anghel, R.G. şi Horvath, I., coord., Sociologia migraţiei. Teorii şi studii de caz româneşti, Iaşi, Editura Polirom, pp. 176194.

Leif, J. (1979), "Ferdinand Tönnies, [Communauté et société]", in Sociologie, Paris, PUF.

Mendras, H. (1989), Elements de sociologie, Paris, Armand Colin.

Mihăilescu, I. (2003), Sociologie generală. Concepte fundamentale şi studii de caz, Iaşi, Polirom.

Pascaru, M. (2003a), Matricea comunitară. Cunoaştere, comunicare şi acţiune comună în satul contemporan, Cluj-Napoca, Presa Universitară Clujeană.

Pascaru, M. (2003b), Sociologia comunităţilor, Cluj-Napoca, Editura Argonaut.

Pascaru, M. (2003c), "Methodological aspects of the identification of the community leaders", în Cristavão, A., Zorini, L. O., ed. (2003), Farming and Rural Systems Research and Extension. Local Identies and Globalisation, Florence, Agenzia Regionale per l'Innovazione e lo Sviluppo in Agricoltura Regione Toscana.

Sandu, D. (2005), Dezvoltare comunitară. Cercetare, practică, ideologie, Iaşi, Editura Polirom.

Sandu, D. (2010), Lumile sociale ale migraţiei româneşti în străinătate, Iaşi, Editura Polirom.

Tönnies, F. (1997), ["Communauté et société"], extrait, in Sociologie, Paris, PUF.

Smelser, N. J. (1981), Sociology, New Jersey, Prentice-Hall, Inc., Englewood Cliffs. 